\title{
Biodiesel from Pyrolysis Fatty Acid Methyl Ester (FAME) using Fly Ash as a Catalyst
}

\author{
Yohandri Bow ${ }^{1, *}$ Abu Hasan ${ }^{2}$, Rusdianasari Rusdianasari ${ }^{2}$, \\ Zakaria Zakaria $^{3}$, Bambang Irawan ${ }^{2}$, Nedia Sandika ${ }^{2}$ \\ ${ }^{1}$ Energy Engineering Department, Politeknik Negeri Sriwijaya, Palembang, Indonesia \\ ${ }^{2}$ Renewable Energy Engineering Department, Politeknik Negeri Sriwijaya, Palembang, Indonesia \\ ${ }^{3}$ English Department, Politeknik Negeri Sriwijaya, Palembang, Indonesia \\ *Corresponding author. Email: yohandri@polsri.ac.id
}

\begin{abstract}
Biodiesel is an environmentally acceptable alternative fuel that has no negative health effects and may be used in vehicles to cut emissions when compared to regular oil. Biodiesel can be produced from the pyrolysis process of Fatty Acid Methyl Ester (FAME) using a fly ash catalyst. The purpose of this study was to obtain biodiesel with a low water content of hygroscopic nature. The pyrolysis process using fly ash catalyst occurs in a temperature range of 141$200^{\circ} \mathrm{C}$, which has an initial boiling point (IBP) of $151^{\circ} \mathrm{C}$. The results showed that the characteristics of the biodiesel produced were following the standards of the Director General of Oil and Gas, namely density 842,500-847,500 $\mathrm{kg} / \mathrm{m}^{3}$, viscosity $3.053-3,371 \mathrm{cSt}, \mathrm{CCI}$ of $48.7-49.7^{\circ} \mathrm{C}$ at $181-200^{\circ} \mathrm{C}$, flash point $58-59^{\circ} \mathrm{C}$, content water $223-218 \mathrm{ppm}$, and sulphur content of $700 \mathrm{ppm}$.
\end{abstract}

Keywords: biodiesel, FAME, fly ash catalyst

\section{INTRODUCTION}

Human activities cannot be separated from the use of fuels derived from fossil energy. The intensity of uncontrolled use and lack of energy conservation poses a problem in fossil fuels availability. The limited reserves of this energy source require serious attention, such as looking for other alternatives by optimizing the use of renewable energy sources. However, the alternatives developed must be able to produce energy in large quantities at low costs and have minimal impact on the environment to replace the fossil energy [1]-[3].

The use of renewable energy sources in the form of biofuels needs to be increased. Considering that the need for fossil fuel sources is increasing every year and these fuels are limited and expensive, it encourages various research and developments to get fuel that is cheaper, environmentally friendly, and from renewable natural materials [4]-[6].

Biodiesel is a biomass-based fuel that can be used to replace petroleum-based diesel. One of the benefits of biodiesel fuel is that it is a renewable energy source that is more environmentally friendly than fossil fuels because it emits far fewer greenhouse gases than fossil fuels. As a result, biodiesel has the potential to solve energy issues in emerging countries, particularly those that do not produce oil [7].

Biodiesel is an alternative fuel from renewable sources with fatty acid ester compositions from vegetable oils, including palm oil, coconut oil, jatropha oil, kapok seed oil. There are still more than 30 kinds of Indonesian plants that have the potential to be used as biodiesel [8]-[10].

The use of vegetable oils directly as fuel for diesel engines has problems, mainly related to the properties of vegetable oils, namely high viscosity, low volatility, and containing unsaturated compounds / more than one double bond (polyunsaturated). However, these properties can be improved in several ways, namely pyrolysis, microemulsification, dilution, and transesterification [11][12].

Based on the content of free fatty acids in vegetable oil, the commercial biodiesel production process usually uses homogeneous catalysts, such as esterification with an acid catalyst and transesterification with a base catalyst. However, the use of this homogeneous catalyst can cause problems in the resulting product, for example, a product that still contains a catalyst, so it must be separated again. In this study, a catalyst was used from coal ash waste (fly ash) which was activated 
so that it would facilitate the separation of the catalyst from the product. Fly ash has a hollow structure composed of several porous oxides, such as $\mathrm{SiO}_{2}$, $\mathrm{Al}_{2} \mathrm{O}_{3}, \mathrm{Fe}_{2} \mathrm{O}_{3}, \mathrm{MgO}$, and $\mathrm{CaO}$ [13]-[15].

Making biodiesel from CPO can be done through esterification and transesterification reactions to convert oil (triglycerides) into fatty acid methyl esters. The content of free fatty acids (FFA) in CPO raw materials is one of the determining factors for the method of making biodiesel. One form of utilization of CPO is processed into FAME so that the specifications are close to petroleum diesel specifications. The study aimed to obtain biodiesel from Fatty Acid Methyl Ester (FAME) through a pyrolysis process using a fly ash catalyst that had been activated using $1 \mathrm{M} \mathrm{NaOH}$, the concentration of the catalyst used was $10 \%$. This biodiesel product is tested for quality based on the value of density, flash point, boiling point, water content and sulphur content of each temperature range which refers to the characteristics and specifications of the quality requirements of the Director General of Oil and Gas [16]-[18].

\section{MATERIAL AND METHOD}

\subsection{Material and Equipment}

The FAME that will be utilized as a sample will be obtained from the tank drainer (the part of the tank that serves to take samples or materials in the tank). After allowing the sample to sit for three days, it was deposited. Figure 1 depicts the pyrolysis apparatus used in the conversion process. Supporting equipment for product analysis includes viscometers, density meters, flash point meters, X-ray sulphur, Karl Fisher Moisture Measurement, and calculated cetane index (CCI).

\subsection{Sampling Method}

The pyrolysis process is carried out in a pyrolysis unit with a 7-liter capacity. The cracking process at temperatures ranging from 161 to $170{ }^{\circ} \mathrm{C}, 171$ to $180{ }^{\circ} \mathrm{C}$, 181 to $190{ }^{\circ} \mathrm{C}$, and $191-200{ }^{\circ} \mathrm{C}$. The volume of liquid fuel produced was measured and recorded. In addition, the condensate is measured with a measuring cup in order to quantify its volume and study its qualities.

\subsection{Sampling Testing}

The density, viscosity, cetane number, flash point, water content, and sulphur content of the fuel product produced from the pyrolysis process with FAME as the raw material are all measured to determine biodiesel quality. To establish the quality of biodiesel obtained from the pyrolysis process, a study examined at the qualities of biodiesel fuel parameters. The parameters of the resulting fuel are compared to those of PT Pertamina
RU III biodiesel to see if there is a drop in quality or if they remain the same, including water content. For 5 days, data was retrieved at temperatures ranging from $161^{\circ} \mathrm{C}$ to $200^{\circ} \mathrm{C}[19]$.

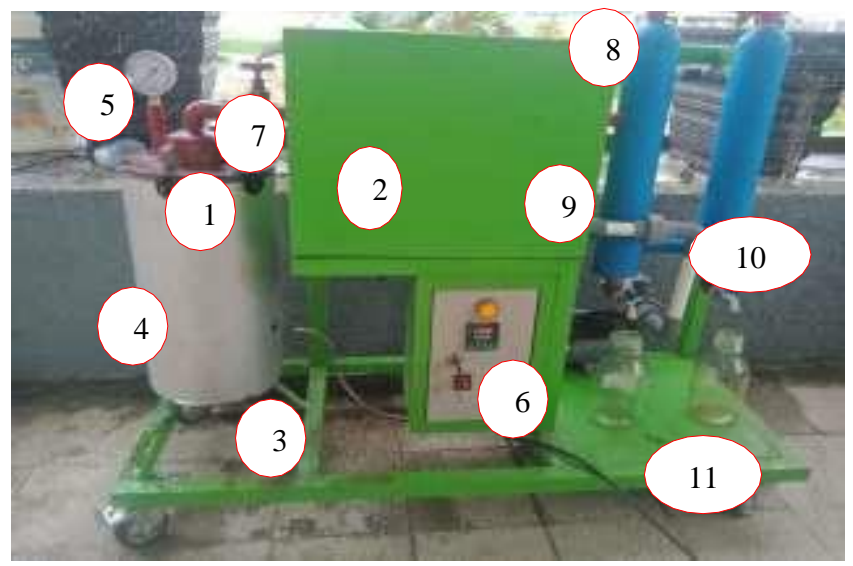

Figure 1. tool

Caption:
1. Reactor,
2. Condenser,
3. Preheater,
4. Stainless steel shell,
5. Pressure control,
6. Thermo Control,
7. Control Valve,
8. Water cooler (inlet),
9. Water cooler (outlet),
10.Output Product,
11.Liquid fuel product tank

\section{RESULTS AND DISCUSSION}

\subsection{Characteristic of Fly Ash as Catalyst}

The fly ash catalyst, which is coal fly ash from the boiler combustion chamber, was tested for its characteristics. Using an Inductivity Coupled Plasma (ICP) instrument, a characteristic test is performed to determine the components present in the fly ash catalyst.

Table 1. The results of an ICP investigation of the Fly Ash catalyst's properties

\begin{tabular}{|c|c|c|c|c|}
\hline Sample & $\begin{array}{c}\text { Analysis } \\
\text { Parameters }\end{array}$ & Method & Unit & Results \\
\hline \multirow{10}{*}{ Fly Ash } & $\mathrm{Al}$ & \multirow{10}{*}{$\begin{array}{c}\text { IP } \\
\text { 501/ASTM } \\
\text { D } 5184\end{array}$} & $\%$ & 7.52 \\
\hline & $\mathrm{Si}$ & & $\%$ & 24.44 \\
\hline & $\mathrm{Fe}$ & & $\%$ & 46.18 \\
\hline & $\mathrm{Ca}$ & & $\%$ & 16.36 \\
\hline & $\mathrm{K}$ & & $\%$ & 0.32 \\
\hline & $\mathrm{Mn}$ & & $\%$ & 0.44 \\
\hline & $\mathrm{Ni}$ & & $\%$ & 0.88 \\
\hline & $\mathrm{Cu}$ & & $\%$ & 0.08 \\
\hline & $\mathrm{Zn}$ & & $\%$ & 0.01 \\
\hline & $\mathrm{V}$ & & $\%$ & 0.01 \\
\hline
\end{tabular}


Based on the table, the content of Fe and Si elements is more significant percentage than other elements. Furthermore, can be concluded based on the composition fly ash entry class $\mathrm{f}\left(\mathrm{SiO}_{2}+\mathrm{Al}_{2} \mathrm{O}_{3}+\mathrm{Fe}_{2} \mathrm{O}\right)$ $>70 \%$ derived from bituminous coal [19].

\subsection{Characteristics of FAME as raw material}

Characteristic results obtained after deposition of at least 3 (three) days $\mathrm{n}$ to determine the characteristics of FAME before using raw materials. The results obtained for the cetane number, density, viscosity, sulphur content, flash point and color are still within the minimum and maximum limits, while the water content is still above the maximum limit, the value can be seen in Table 2.

Table 2. Result of FAME analysis as raw material

\begin{tabular}{|l|c|c|}
\hline \multicolumn{1}{|c|}{ Characteristics } & Units & Results \\
\hline Cetane Number & -- & 58.3 \\
\hline Density @ $15^{\circ} \mathrm{C}$ & $\mathrm{kg} / \mathrm{m}^{3}$ & 854 \\
\hline Viscosity @ $40{ }^{\circ} \mathrm{C}$ & $\mathrm{mm}^{2} / \mathrm{sec}$ & 4.83 \\
\hline Sulphur Content & $\% \mathrm{~m} / \mathrm{m}$ & 0.07 \\
\hline $\begin{array}{l}\text { Evaporation point @ } \\
\text { Distillation } 90 \%(\mathrm{vol})\end{array}$ & ${ }^{\circ} \mathrm{C}$ & 333 \\
\hline Flash Point & ${ }^{\circ} \mathrm{C}$ & 152 \\
\hline Moisture Content & $\mathrm{mg} / \mathrm{kg}$ & 623 \\
\hline Colour & - & 1 \\
\hline
\end{tabular}

\subsection{The density of biodiesel from $F A M E$ pyrolysis at temperature range of $141-200^{\circ} \mathrm{C}$}

The calorific value and power produced by the combustion process of fuel are affected by density. A high density value indicates that the fuel contains a large number of components. This component will increase the calorific value of the fuel combustion process by extending the atomization process of the fuel components during the combustion process.

According to the Director General of Oil and Gas's quality standard, the required density for biodiesel is $815-860 \mathrm{~kg} / \mathrm{m}^{3}$ at $15{ }^{0} \mathrm{C}$. A density value that meets the required quality standards can produce a complete combustion reaction in the engine, whereas a density value that exceeds the standard causes the combustion reaction to become imperfect, increasing emissions and engine wear. Figure 2 depicts the results of the analysis of the density value of biodiesel fuel [20].

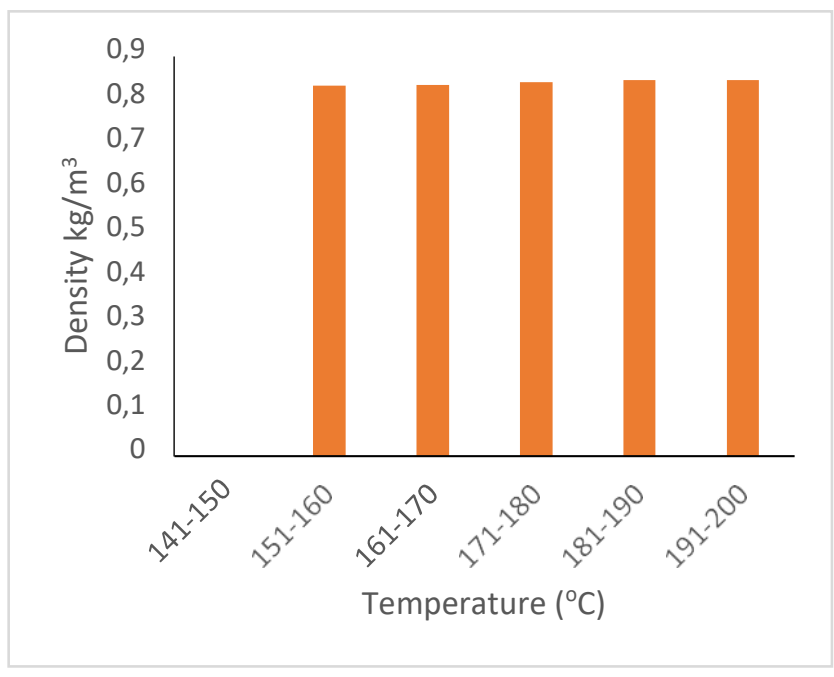

Figure 2. Biodiesel Density Result of FAME Pyrolysis

Figure 2 shows that for the composition of FAME raw materials with Fly Ash catalyst starting from a temperature of $151-160^{\circ} \mathrm{C}$ with a density of 0.8350 $\mathrm{kg} / \mathrm{m}^{3}, 161-170^{\circ} \mathrm{C}$ density $0.8360 \mathrm{~kg} / \mathrm{m}^{3}, 171-180^{\circ} \mathrm{C}$ density $0.8425 \mathrm{~kg} / \mathrm{m}^{3}, 181-190^{\circ} \mathrm{C}$ density $0.8465 \mathrm{~kg} / \mathrm{m}^{3}$ and $191-200^{\circ} \mathrm{C}$ density $0.8475 \mathrm{~kg} / \mathrm{m}^{3}$. All of them obtained the results of density analysis between the minimum and maximum limits of the required quality standards. When viewed from the temperature range, the density value of the biodiesel product is heavier if the biodiesel product is obtained at a higher temperature [21].

\subsection{Viscosity of biodiesel resulting from FAME pyrolysis at temperature range of $141-200^{\circ} \mathrm{C}$}

A high viscosity will increase friction loss in the pipe, make the pump work harder, and complicate the filtering process, increasing the possibility of dirt settling and fuel fogging. A low viscosity causes the lubrication to thin, causing wear and damage to the combustion engine [22].

FAME's kinematic viscosity is nearly twice that of diesel oil, which is critical for engine lubrication. FAME is a vegetable-derived material with low sulphur and aromatics content. Furthermore, the level of Particulate Matter emissions produced is lower (PM). The required biodiesel viscosity value at $40 \mathrm{oC}$, according to the Director General of Oil and Gas, is 2.0$4.5 \mathrm{cSt}$.

Figure 3 depicts the results of an analysis of the viscosity value of biodiesel fuel. Figure 3 shows that for the composition of FAME raw materials with Fly Ash catalyst starting from a temperature of $151-160^{\circ} \mathrm{C}$ with a viscosity of $2.459 \mathrm{cSt}, 161-170^{\circ} \mathrm{C}$ viscosity $2.652 \mathrm{cSt}$, $171-180^{\circ} \mathrm{C}$ viscosity $3.053 \mathrm{cSt}, 181-190^{\circ} \mathrm{C}$ viscosity $3.262 \mathrm{cSt}$ and $191-200^{\circ} \mathrm{C}$ viscosity $3,371 \mathrm{cSt}$. When viewed from the temperature range, the viscosity value of biodiesel products is greater if the biodiesel yields are obtained at higher temperatures [23]. 


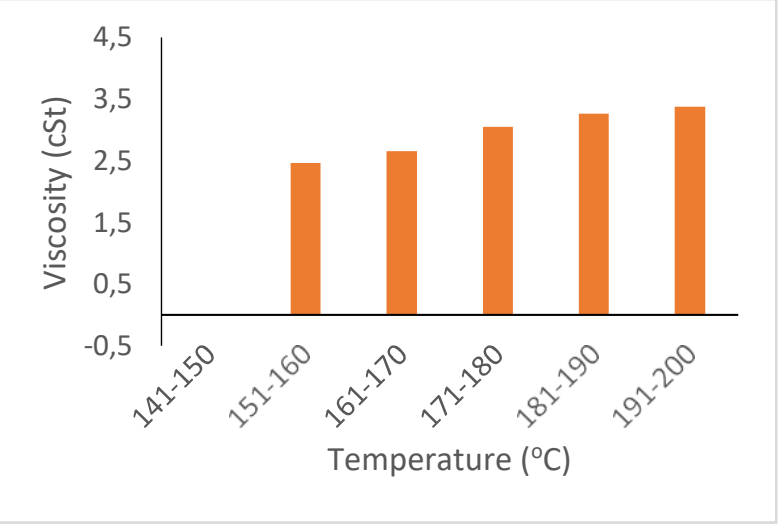

Figure 3. Biosolar Viscosity of FAME Pyrolysis

\subsection{Calculated cetane index (CCI) of biodiesel from FAME pyrolysis at temperature range of 141-200 ${ }^{\circ} \mathrm{C}$}

The cetane number is a number that shows the results of testing the combustion quality of a diesel fuel by comparing the reference fuel with the known cetane number in advance. The FAME cetane number according to SNI is at least 51 , while the standard for petroleum diesel according to the Director General of Oil and Gas is at least 48 and the Calculated Cetane Index (CCI) is at least 45 .

The cetane number indicates how quickly diesel engine fuel can be injected into the combustion chamber so that it burns spontaneously in the engine. The cetane number of petroleum diesel is influenced by the structure of the constituent hydrocarbons. The lower the cetane number, the lower the ignition quality because it requires a higher ignition temperature.

FAME has a higher cetane number or calculate cetane index (CCI) than petroleum diesel, making it ideal for boosting auto-ignition in diesel engines. The more devils there are, the longer the fatty acid's carbon chain is and the more saturated the molecule is [24].

The results of the CCI analysis of biodiesel fuel at various temperature ranges can be seen in Figure 4.

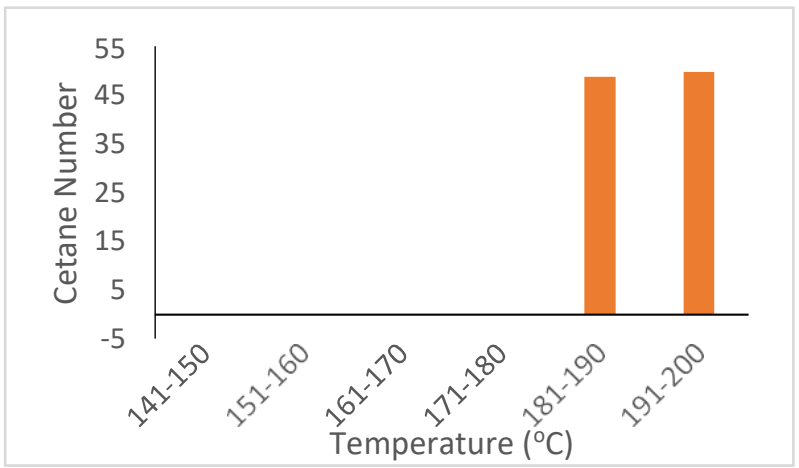

Figure 4. Calculated Cetane Index (CCI) of FAME Pyrolysis
The ASTM D613-80 method is a measurement method in determining the quality of biodiesel combustion or also said to determine the cetane number of diesel fuel, for the composition of FAME raw materials with Fly Ash catalyst starting from a temperature of $181-190^{\circ} \mathrm{C}$ with a cetane number of 48.7 and $191-200^{\circ} \mathrm{C}$ a cetane number of 49.7. The temperature range obtained by the CCI analysis value is above the minimum quality limit required by the Director General of Oil and Gas.

\subsection{Flash point of biodiesel from FAME pyrolysis at temperature range of $141-200^{\circ} \mathrm{C}$}

The flash point value of FAME is much higher than the flash point value of petroleum diesel, so the blending formulation with more FAME composition will result in the flash point of the biodiesel produced also increasing. The flash point of biodiesel also increased every week for one month of storage. Referring to the quality requirements of the Director General of Oil and Gas, the flash point of each biodiesel product composition has passed the minimum required limit [25]. In the quality requirements of the Director General of Oil and Gas, the flash point value is set at a minimum value of $52^{\circ} \mathrm{C}$ for petroleum-based diesel fuel. The flash point value (flash point) of biodiesel fuel that has been obtained from this study can be seen in Figure 5.

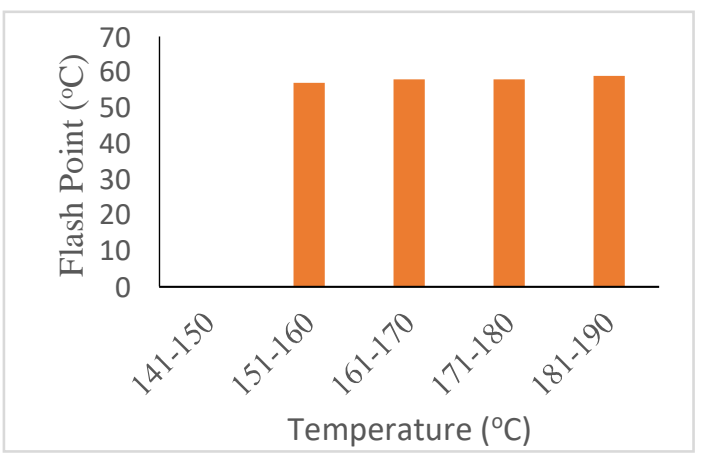

Figure 5. Flash Point of Biodiesel Results of Pyrolysis

Figure 5 shows that for the composition of FAME raw materials with Fly Ash catalyst starting from a temperature of $151-160^{\circ} \mathrm{C}$ with a flash point of $57^{\circ} \mathrm{C}$, $161-170^{\circ} \mathrm{C}$ flash point $58^{\circ} \mathrm{C}, 171-180^{\circ} \mathrm{C}$ flash point $58^{\circ} \mathrm{C}, 181-190^{\circ} \mathrm{C}$ flash point $58^{\circ} \mathrm{C}$ and $191-200^{\circ} \mathrm{C}$ flash point $60^{\circ} \mathrm{C}$. All of them obtained the results of flash point analysis above the minimum required quality standard. When viewed from the temperature range, the flash point value of biodiesel products is higher if the biodiesel yields are obtained at higher temperatures [26]. 


\subsection{The water content of biodiesel from $F A M E$ pyrolysis at temperature range of $141-200^{\circ} \mathrm{C}$}

In some countries with winters, the water content in diesel engine fuel might crystallize, obstructing the passage of fuel via the injectors. Furthermore, water can promote corrosion and the growth of microorganisms, which can clog the combustion chamber and prevent fuel from entering. Clogging and engine damage can also be caused by sediment [27].

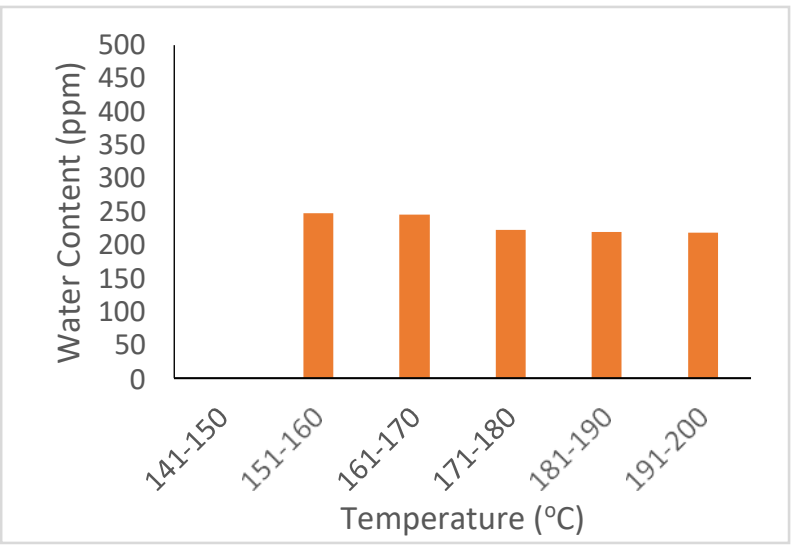

Figure 6. Water content of FAME Pyrolysis Results

Figure 6 shows that for the composition of FAME raw materials with Fly Ash catalyst starting from a temperature of $151-160^{\circ} \mathrm{C}$ with a water content of 248 ppm, $161-170^{\circ} \mathrm{C}$ water content $245 \mathrm{ppm}, 171-180^{\circ} \mathrm{C}$ water content $223 \mathrm{ppm}, 181-190^{\circ} \mathrm{C}$ water content 219 ppm and $191-200^{\circ} \mathrm{C}$ water content $218 \mathrm{ppm}$. All water content analysis results are below the maximum required quality standard and are in accordance with the objectives of this study. When viewed from the temperature range, the value of the water content of biodiesel products is less if the biodiesel yields are obtained at higher temperatures.

\subsection{Sulphur content of biodiesel resulting from FAME pyrolysis at a temperature range of 141 - $200^{\circ} \mathrm{C}$}

Sulphur is the biggest adversary of diesel engines, as the higher the sulphur concentration, the more acidic the engine will become. Engine components, from scale to fuel lines, will be damaged as a result of this circumstance. Crust in the fuel lines can obstruct the flow of fuel into the cylinders, resulting in a direct impact on engine performance, ranging from lower power to more significant damage. Premature combustion, often known as knocking, occurs here, causing the engine to tickle [9].

Injector components can be damaged by high sulphur levels, resulting in poor combustion. The cleaner the exhaust gas emissions, fuel lines, diesel filters, and combustion chamber are, the lower the sulphur content. Sulphur also affects engine life. The higher the sulphur which is acidic, the more the engine will rust easily [14].

High sulphur levels in diesel fuel have consequences that go beyond vehicle harm. When combustion gases from an engine are mixed with air, sulphur dioxide $\left(\mathrm{SO}_{2}\right)$ is formed, and when $\mathrm{SO}_{2}$ is coupled with water vapor, an acidic composition is formed, which is damaging to the body [26].

FAME is devoid of nitrogen and aromatic molecules, with a sulphur content of less than 155 ppm (parts per million) [9]. FAME also includes $11 \%$ oxygen by weight, which lowers energy content while also lowering exhaust gas emissions such as carbon monoxide (CO), hydrocarbons ( $\mathrm{HC})$, particulates, and soot. Biodiesel has a lower energy content than diesel, but its fuel efficiency is similar to petroleum diesel, which implies that the power and torque produced are proportionate to the calorific value content of the combustion.

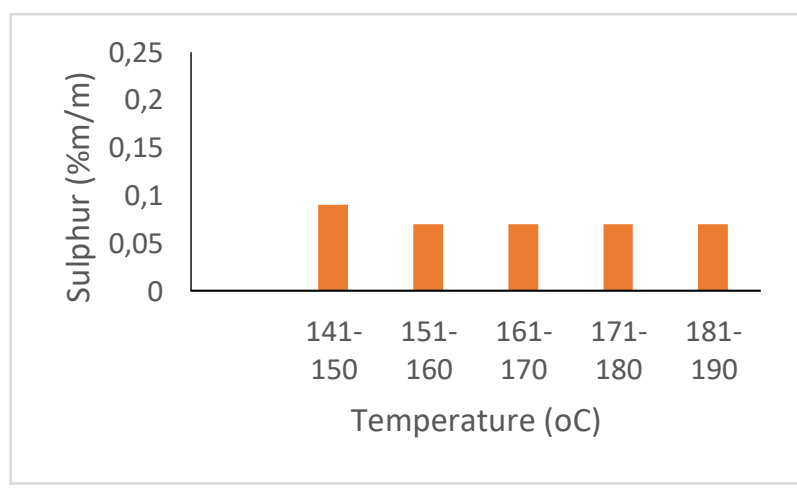

Figure 7. Sulphur content of biodiesel from FAME pyrolysis

Figure 7 shows that the composition of FAME raw materials with Fly Ash catalyst starts at a temperature of $151-160^{\circ} \mathrm{C}$ with a sulphur value of $0.09 \% \mathrm{w} / \mathrm{w}$, and $161-$ $200^{\circ} \mathrm{C}$ a sulphur value of $0.07 \% \mathrm{w} / \mathrm{w}$. Everything is obtained from the analysis that the sulphur content of biodiesel is far below the maximum required limit.

\section{CONLUSION}

Biodiesel is an environmentally friendly diesel fuel, according to the pyrolysis results, because it creates lower exhaust pollutants, namely free sulphur. The sulphur content of 0.1 percent $\mathrm{w} / \mathrm{w}$ is well below the quality standard limit's maximum value. According to the findings, the viscosity density value of the cetane number, flash point of water content, and sulphur value of biodiesel are still within the range of the Director General of Oil and Gas' quality criteria.

\section{AUTHORS' CONTRIBUTIONS}

All of the authors are involved in the process of designing the equipment and analysis biodiesel. The first and corresponding author contribution is 
responsible for data processing and manuscript writing. The second author is responsible for equipment design and data processing. The third author is responsible for analysis biodiesel sample. The fourth author is responsible for funding arrangement.

\section{ACKNOWLEDGMENTS}

The author would like to express profound gratitude to the Politeknik Negeri Sriwijaya which has funded this research through the 2021 Leading Postgraduate Applied Research.

\section{REFERENCES}

[1] I. Anindhita, I. Rahardjo, R. Fitriana, E P Dewi, Outlook Energi Indonesia 2018. Jakarta: Pusat Pengkajian Industri Proses dan Energi (PPIPE) Badan Pengkajian dan Penerapan Teknologi (BPPT), 2018.

[2] $\mathrm{R}$ Ploetz, $\mathrm{R}$ Rusdianasari, E Eviliana, Renewable Energy: Advantages and Disadvantages Proceeding Forum in Research, Science, and Technology (FIRST), pp. E1-E4, 2016.

[3] RAN Moulita, Rusdianasari, L Kalsum, Converting Waste Cooking Oil into Biodiesel using Microwaves and High Voltage Technology, Journal of Physics: Conf. Series 1167(012033), 2019

[4] S Yunsari, Rusdianasari, A Husaini, CPO Based Biodiesel Production using Microwaves Assisted Method, Journal of Physics: Conf. Series 1167(1) 012036, 2019

[5] P Dilia, K Leila, Rusdianasari, Fatty Acids from Microalgae Botryococcusbraunii for Raw Material of Biodiesel, Journal of Physics: Conf. Series 1095(012010), 2018.

[6] L Hakim, Rusdianasari, L. Kalsum, The Optimum Yield of nannochloropsis sp Microalgae from the Lipid Cultivation and Extraction Process with Soxhlet Method,

[7] S Mothil, V C Devi, R S Raam, P Asmitha, A Gokul, B Balakumar, Biodiesel Production from waste Cooking Oil through Transesterification using Novel Double Layered Hydroxide Catalyst, AIP Conference Proceeding 2387, 120004, 2021.

[8] Rusdianasari, A Syarif, M Yerizam, MS Yusi, L Kalsum, Y Bow, Effect of Catalyst on the Quality of Biodiesel from Waste Cooking oil by
Induction Heating, Journal of Physics: Conf. Series 1500 (012052), 2020

[9] Bemani, Amin, Modeling of cetane number of biodiesel from fatty acid methyl ester (FAME) information using GA-, PSO-, and HGAPSO- LSSVM models, Renewable Energy 150, pp. 924-934, 2020

[10] M Khan, H Farah, N Iqbal, T Noor, MZB Amjad, SSE Bukhari, A TiO2 Composite with Graphite Carbon Nitride as a Photocatalyst for Biodoesel Production from Waste Cooking Oil, Royal Society of Chemistry, 11, pp. 3757537583, 2021.

[11] Juarsa, A Syarif, L Kalsum, Effect of Feed Composition and Product Quality of CoProcessing Refined Blended Deodorized Palm oil (RBDPO), Proceeding of the $4^{\text {th }}$ Forum in research, Science, and Technology (FIRST-T1T2-2020), Atlantis Highlights in Engineering, Vol. 7, pp. 1-7, 2021.

[12] Yusabri, M Yerizam, A Syarif, Characterization of Blending Composition Variations in Fatty Acid Methyl Ester (FAME) Biofuels with Diesel to Biodiesel, Proceeding of the $4^{\text {th }}$ Forum in research, Science, and Technology (FIRSTT1-T2-2020), Atlantis Highlights in Engineering, Vol. 7, pp. 35-40, 2021.

[13] Khanam T, Khalid F, Manzoor W, Rashedi A, Hadi R, Ullah F, Environmental sustainability assessment of biodiesel production from Jatropha curcas L. seeds oil in Pakistan. PLoS ONE 16(11): e0258409. 2021. https://doi.org/10.1371/journal.pone.0258409

[14] ES Yusmartini and Rusdianasari, Separation process Biodiesel from Waste Cooking Oil using Ultrafiltration Membranes Proceeding Forum in Research, Science, and Technology (FIRST), 2016.

[15] S Susumu, R Rusdianasari, S Yusi 2018 Biodiesel Production from Waste Cooking Oil using Electrostatic Method Indonesia Journal of Fundamental and Applied Chemistry (IJFAC) 3(3)

[16] JU Putra, L Kalsum, Y Bow 2018 Effect of DC Voltage on Prototype of Biodiesel Electrostatic Separator with Glyserin from Waste Cooking Oil Indonesia Journal of Fundamental and Applied Chemistry (IJFAC) 3(3)

[17] E Anzar, S Yusi, Y Bow 2018 Purification of Crude Glycerol for Biodiesel By-product by Adsorption using Bentonite Indonesia Journal of Fundamental and Applied Chemistry (IJFAC) 3(3) 
[18] G Uguz, Inhibitory Effect of Thyne Oil as an Antioxidant for Waste Cooking Oil Biodiesel Crystallization, Energy and Environment, 2021, http://doi.org/10.1177/0958305X2110613 46

[19] B Irawan, Rusdianasari, A Hasan, Pyrolysis Process of Fatty Acid Methyl Ester (FAME) Conversion into Biodiesel, Int. Journal of Research in Vocational Studies (IJRVOCAS) 1(2), pp. 01-10, 2021

[20] Kukana, R., Jakhar, O.P. An appraisal on enablers for enhancement of waste cooking oil-based biodiesel production facilities using the interpretative structural modeling approach. Biotechnol Biofuels 14, 213, 2021, https://doi.org/10.1186/s13068-021 02061-2

[21] RAN Moulita, R Rusdianasari, L Kalsum 2020 Biodiesel production from Waste Cooking Oil using Induction Heating Technology Indonesia Journal of Fundamental and Applied Chemistry (IJFAC) 5(1)

[22] Rusdianasari, Y Bow, RAN Moulita 2020 Temperature Effect on the Biodiesel Quality from Waste Cooking Oil by Induction Heating Journal of Physics: Conf. Series 1450012003
[23] Djayasinga, R., Setiawan, A., Purnomo, A., Amien, A. Z. and Hartanti, H, Utilization of Breed Chicken Eggshells to Make Biodiesel from Waste Cooking Oil, Journal of Multidisciplinary Applied Natural Science. Metro, Indonesia. 2021, doi: 10.47352/jmans.2774-3047.90.

[24] S. Yunsari, A. Husaini, and Rusdianasari, Effect of Variation of Catalyst Concentration in the Producing of Biodiesel from Crude Palm Oil using Induction Heater, Asian Journal of Applied Research and Community Development and Empowerment, Vo. 3(1), pp. 24-27., 2019

[25] Tongroon, M., Suebwong, A., Kananont, M., Aunchaisri, J., \& Chollacoop, N. High quality jatropha biodiesel (H-FAME) and its application in a common rail diesel engine. Renewable Energy, 113,pp. 660-668, 2017.

[26] V D’Ambrosio, L di Bitonto, A Angelini, A Gallipoli, C.M. Braguglia, C Pastore, Lipid Extraction from Sewage Sludge using Green Biosolvent for Sustainable Biodiesel Production, Journal of Cleaner Production, Vol. 329, 129643, 2021.

[27] Meriatna, Zalmiardi, Suryati, Sulhatun, ZD Nasution, Rahmadhani, Application of Pisang Awak Bunch-Derived Heterogeneous Base Catalyst in Transesterification of Palm Oil into Biodiesel, International Jpurnal of Engineering, Science, and Information Technology, Vol. 2 No. 1, 2022. 